\title{
Studies on Biosorption of Mercury (II) from Aqueous Solution on Nitric Acid Modified Activated Carbon Prepared from Water Hyacinth
}

\author{
A.M. El-Wakil ${ }^{1}$, W.M. Abou El-Maaty ${ }^{2}$, F.S. Awad ${ }^{3}$ \\ ${ }^{1}$ Professor,Chemistry Department, Faculty of Science, Mansoura University, Mansoura, EGYPT \\ ${ }^{2}$ Lecturer,Chemistry Department, Faculty of Science, Mansoura University, Mansoura, EGYPT \\ ${ }^{3}$ Assistant Lecturer, Chemistry Department, Faculty of Science, Mansoura University, Mansoura, EGYPT
}

\begin{abstract}
The aim of this study was focused on using dried Water hyacinth stems and leaves (DS, DL) and nitric acid modified activated carbon stems and leaves (MACS, MACL) as effective adsorbents for removal of $\mathrm{Hg}$ (II) from aqueous solutions. Adsorption experiments were performed in batch technique to study the effect of various operating parameters, $\mathrm{pH}$ of the solution (1 to 5.5), initial concentration of lead ions (10 to $500 \mathrm{mg} / \mathrm{l})$, contact time (2 - $250 \mathrm{~min})$, and temperature(298- $323 \mathrm{~K})$, ionic strength, and adsorbent dose. It is clear that the maximum adsorption capacity of mercury at $\mathrm{pH} 5$ and $298 \mathrm{~K}$ onto MACS, MACL, DL and DS was 102.6, 81.9, 57.59 and $41.70 \mathrm{mg}$. g-1, respectively. The obtained results revealed that the percentage of mercury removal increased with increased contact time till reach to the equilibrium time $(60 \mathrm{~min})$. When the bio sorbent dosage increased from 0.4 to $4 \mathrm{~g} / \mathrm{L}$, the percent of mercury removal by DS, DL, MACS and MACL increased from $37.43 \%$ to $79.58 \%$, from $32.59 \%$ to $78.27 \%$, from $41.49 \%$ to $82.33 \%$ and from $28.66 \%$ to $87.17 \%$, respectively. The adsorption capacity of mercury decreased with the increase in ionic strength. The equilibrium data were fitted well with the linear form of Langmuir model. Adsorption kinetic data followed a pseudo-second-order model. Thermodynamic parameters, involving $\Delta \mathrm{H}^{\circ}, \Delta \mathrm{G}^{\circ}$, and $\Delta \mathrm{S}^{\circ}$ for the adsorption process of mercury from aqueous solution onto dried water hyacinth and modified activated carbon indicated that adsorption was endothermic and spontaneous process. Desorption were also investigated using $\mathrm{HCl}$ as desorbing agent. The results revealed that the percent recovery of $\mathrm{Hg}$ (II) increased from $53 \%$ to about $88 \%$ with increase of $\mathrm{HCl}$ from 0.3 to $0.8 \mathrm{M}$ and then remained constant.
\end{abstract}

Key words: Water hyacinth, Nitric acid, Adsorption, Modified activated carbon, Desorption, Mercury

\section{INTRODUCTION}

Mercury, as one of the known toxic metals, can be found in wastewaters of some industries, including chloralkali, battery, pulp paper, oil refining, electrical, rubber processing, and fertilizer industries (Horvat etel, 1996). A unique characteristic of mercury is its extensive adsorption into biological tissues and slow elimination from them. Mercury can be adsorbed 
in the body through gastrointestinal tract, skin, and lungs. As a heavy metal, mercury circulates in the blood and accumulates in some vital organs such as liver, kidneys, brain, spleen, and bone after adsorption in body. This may lead to serious health problems including pulmonary and kidney malfunctions, damages to chromosomes, adverse effects on central nervous system, and in severe cases, death.

Consequently, removal of mercury ions from waste waters is a very important issue. For this reason, various technological methods are available, including lime softening, chemical precipitation, coagulation, solvent extraction, reverse osmosis, ion exchange, volatilization, membranefiltration, and activated carbon adsorption. Adsorption isamongthemostextensivelyusedmethodsfor up-takingmetalions. Recently, numerous approaches have been studied for the development of cheaper and effective adsorbents. Many low cost adsorbents, including natural materials, bio sorbents, and waste materials from agriculture and industry, have been proposed by several workers such as orange peel, and Apricot stones (Demirbas etel, 2008). These materials could be used as adsorbents for the removal of $\mathrm{Hg}$ (II) from solution (Attia etel, 2008). Water hyacinth (WH) is aquatic plant belongs to the family Pontederiaceae, order Liliiflorae (Monocotyledoneae). The WH propagates both by seed germination and by vegetative means where by mature plants produce rosettes of leaves and fibrous roots at each node of the growing stem. A single plant can produce approximately 65,000 offspring during a single season. Water hyacinth can cause a variety of problems when its rapid mat-like proliferation covers areas of fresh water.

The aim of this study was to deal with the rapidly expanding carpets of water hyacinth. The idea was to prepare activated carbon from the pyrolys is of water hyacinth and evaluate the potentiality of DS, DL, MACS, and MACL for the removal Hg (II) from aqueous solution. The effects of initial $\mathrm{Hg}$ (II) concentration, contact time, solution $\mathrm{pH}$, adsorbent dosage, and temperature on $\mathrm{Hg}$ (II) adsorption were evaluated. The adsorption kinetics, is other ms and temperature dependent performance, were investigated.

\section{EXPERIMENTAL}

\section{Materials and reagents}

Stock solution of mercury

Containing $1 \mathrm{mg}$ mercury $\mathrm{cm}^{-3}$ was prepared by dissolving $1.3535 \mathrm{~g}$ of $\mathrm{HgCl}_{2}$ in distilled water acidified with $\mathrm{HCl}$ and this solution is completed up to the mark of $1 \mathrm{~L}$ measuring flask. Mercury solutions of lower concentrations were prepared by further dilution with $0.001 \mathrm{MHCl}$.

\section{PAR solution}

PAR (2-pyridylazoresorcinol) solution $0.1 \%(\mathrm{w} / \mathrm{v})$ prepared by dissolving $0.1 \mathrm{~g}$ of solid substance in least amount of distilled water then transfers to $100 \mathrm{ml}$ measuring flask and complete to the mark using distilled water.

\section{Spectro photo metric determination of $\mathrm{Hg}^{2+}$}

Add $1 \mathrm{ml}$ of PAR $(0.1 \mathrm{~g} / 100 \mathrm{ml})+10 \mathrm{ml}$ of borate buffer $\mathrm{pH}=9+\mathrm{X} \mathrm{ml}$ of metal in $25 \mathrm{ml}$ measuring flask then complete to the mark with distilled water to obtain a final concentration of $(0.5,1,2,3,4,5 \mathrm{ppm})$ and shake well. Measure the absorbance of the solutions at wave length $=522 \mathrm{~nm}$ and construct the standard calibration curve. The 
absorbance of unknown sample was measured at the same wave length and the concentration was determined from the standard calibration curve.

\section{Preparation of Adsorbents}

The modified activated carbon stems (MACS) and leaves (MACL) were prepared from water hyacinth collected from Canal extended from river Nile in Mansoura, Egypt according to the following steps as shown in Fig.1.

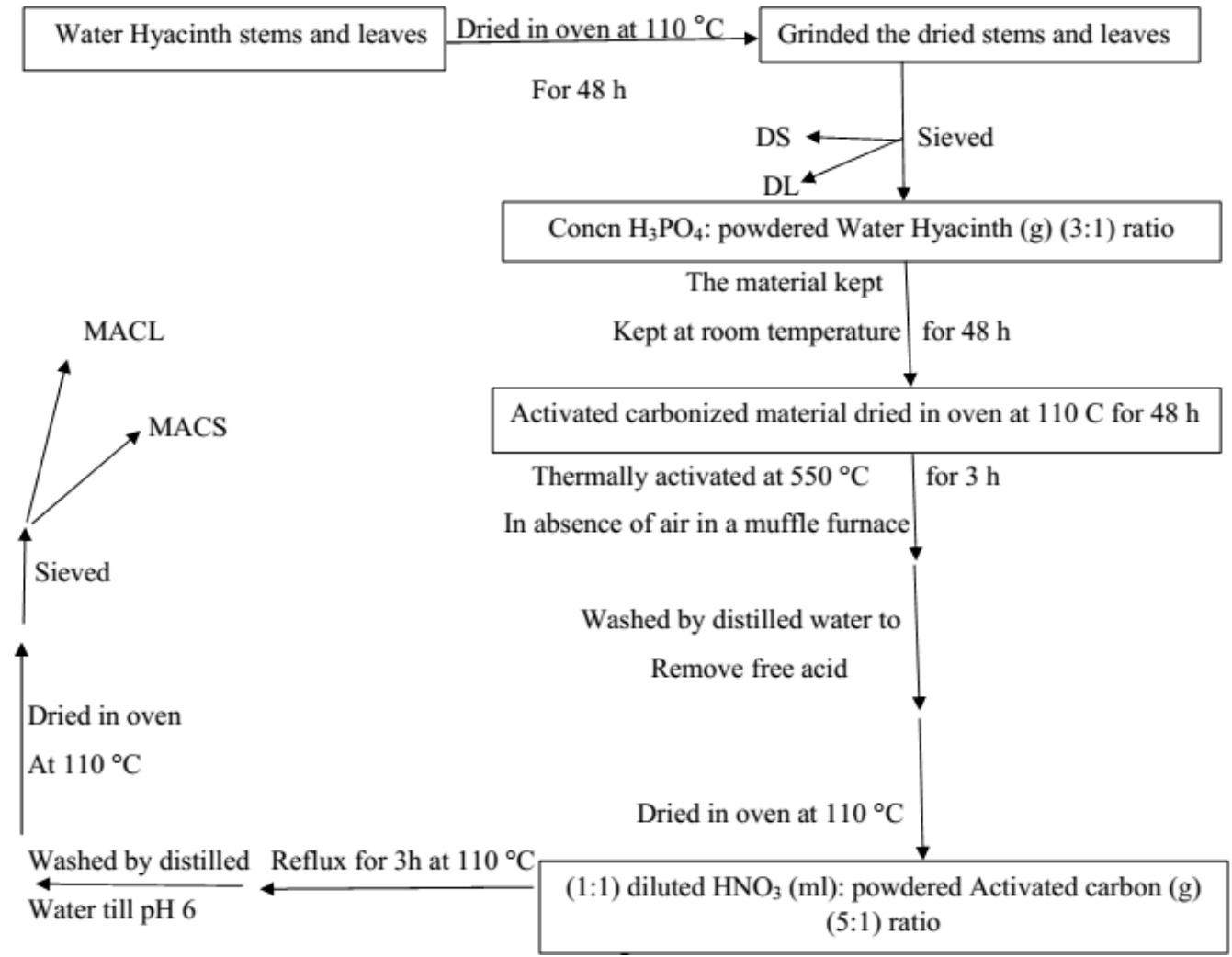

Figure 1: Schematic diagram of water hyacinth biomass-derived modified activated carbon.

\section{Batch adsorption experiments}

Batch sorption experiments were done by shaking $0.025 \mathrm{~g}$ of each adsorbent DS, DL, MACS, and MACL with $25 \mathrm{ml}$ aqueous solution of $\mathrm{Hg}$ (II) in $250 \mathrm{ml}$-Erlenmeyer flasks placed in a temperature controlled shaking water bath at different concentrations (between 10 and $500 \mathrm{mg} / \mathrm{L}$ ), pHs (between 1 and 5.5), ionic strength (between 0.05 and 0.5 $\mathrm{mol} / \mathrm{L} \mathrm{NaCl}$ ), temperatures (between 25 and $50{ }^{\circ} \mathrm{C}$ ) and sorbent doses (between 0.01 and $0.1 \mathrm{~g}$ ) at a constant shaking rate of $125 \mathrm{rpm}$. The amounts of $\mathrm{Hg}$ (II) removed by sorbents $\mathrm{q}_{\mathrm{e}}$ and percent extracted $\% \mathrm{E}$ can be calculated using the following equations:

$$
\begin{aligned}
& \text { Extraction } \%=\frac{\left(C_{0}-C_{e}\right)}{C_{0}} \times 100 \\
& q_{e}=\frac{\left(C_{0}-C_{e}\right) V}{m}
\end{aligned}
$$


Where qe is the amount of dye adsorbed $(\mathrm{mg} / \mathrm{g}) . \mathrm{C}_{\mathrm{o}}$ and $\mathrm{C}_{\mathrm{e}}$ are the initial and equilibrium liquid-phase concentrations of $\mathrm{Hg}$ (II) $(\mathrm{mg} / \mathrm{g})$, respectively. $\mathrm{V}$ is the volume of the solution $(\mathrm{L})$, and $\mathrm{m}$ is the weight of the sorbent used $(\mathrm{g})$.

For kinetic studies, $100 \mathrm{ml}$ of $250 \mathrm{ppm}$ of $\mathrm{Hg}$ (II) solution of known amount of adsorbent $(0.1 \mathrm{~g})$ were taken in a $100 \mathrm{ml}$ Stoppard bottle and agitated at $150 \mathrm{rpm}$. Samples were withdrawn at different time intervals (2-300 $\mathrm{min}$ ), and analyzed for remaining $\mathrm{Hg}$ (II) concentration. The amount of $\mathrm{Hg}$ (II) removed by adsorbent at time $\mathrm{t}$, qt can be calculated by using equation (2).

\section{Desorption Studies}

Batch experiments were conducted to evaluate desorption of $\mathrm{Hg}$ (II) from DS, DL, MACS, and MACL using $\mathrm{HCl}$ as desorption chemical solution. Initially, $25 \mathrm{ml}$ of 250 ppm mercury solution were added into $100 \mathrm{ml}$ a conical flask containing $25 \mathrm{mg}$ of DS, DL, MACS, and MACL. After about $7 \mathrm{~h}$ of rotation, the residual $\mathrm{Hg}$ (II) concentration in the supernatant was determined. The bio sorbent was filtered and washed three times with distilled water. Subsequently, $25 \mathrm{ml}$ of $x \mathrm{MHCl}$ desorption solution were introduced and the system bio-sorbent eluting agent was rotated for $7 \mathrm{~h}$. Finally, the desorbed $\mathrm{Hg}$ (II) concentration in the aqueous phase was determined.

\section{Result AND Discussion}

\section{Effect of nitric acid treatment on the surface area, porous structure, and surface functional groups.}

Table 1. shows the Surface area of dried water hyacinth( stems, leaves) and modified activated carbon (stems, leaves) were determined from the application of BET equation to the adsorption-desorption isotherm of $\mathrm{N}_{2}$ at 77k (Minczewskietel, 1982). It clears that the surface area of dried stems and leaves are relatively small $(57.46,71.83)$ while modified activated carbon samples with nitric acid have a larger surface area $t$, reaching the surface area for MACS to 381.22 and for MACL to 365.22. The function of nitric acid is the destruction of the cellulosic structure, enhancing thermal degradation, creation of porous carbonization product.

Examination of the surface nature morphology and porosity of different adsorbents using scanning electron microscope. Fig.2. reveals that the adsorbents MACS and MACL at magnification of 1000x are more porous than DS and DL at magnification 1500x.

FTIR spectra is used to prove the chemical composition and acidic groups on the surface. Oxidation with concentrated nitric acid creates new carboxylic groups. This is indicated by the appearance of a sharp absorption peak at $1608-1713 \mathrm{Cm}^{-1}$ for MACL and MACS are due to stretching vibration of carboxyl groups on the edges of layer plane (Macías-Garcíaietel, 2006) as shown in fig.3.

Table 1: Characteristics of the dried Water hyacinth (stems and leaves), activatedcarbon and modified activated carbon (stems and leaves).

\begin{tabular}{|c|c|c|c|c|}
\hline & DS & DL & MACS & MACL \\
\hline Surface Area $\left(\mathrm{m}^{2} / \mathrm{g}\right)$ & 57.46 & 71.83 & 381.22 & 365.22 \\
\hline Total pore volume $(\mathrm{cc} / \mathrm{g})$ & 0.01 & 0.03 & 0.43 & 0.29 \\
\hline
\end{tabular}



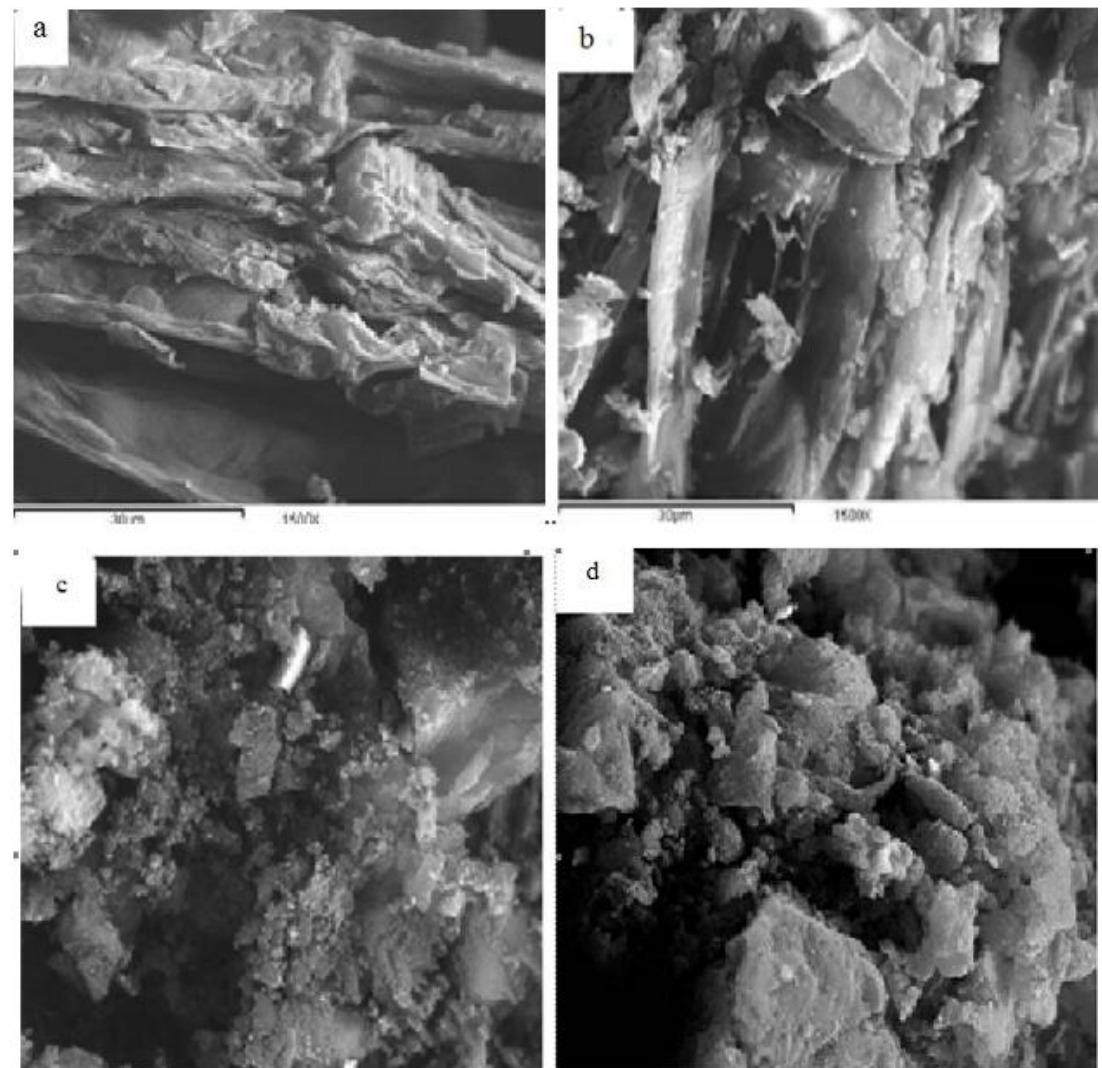

Figure 2: SEM photographs of (a) DS, (b) DL, (c) MACS, (d) MACL.

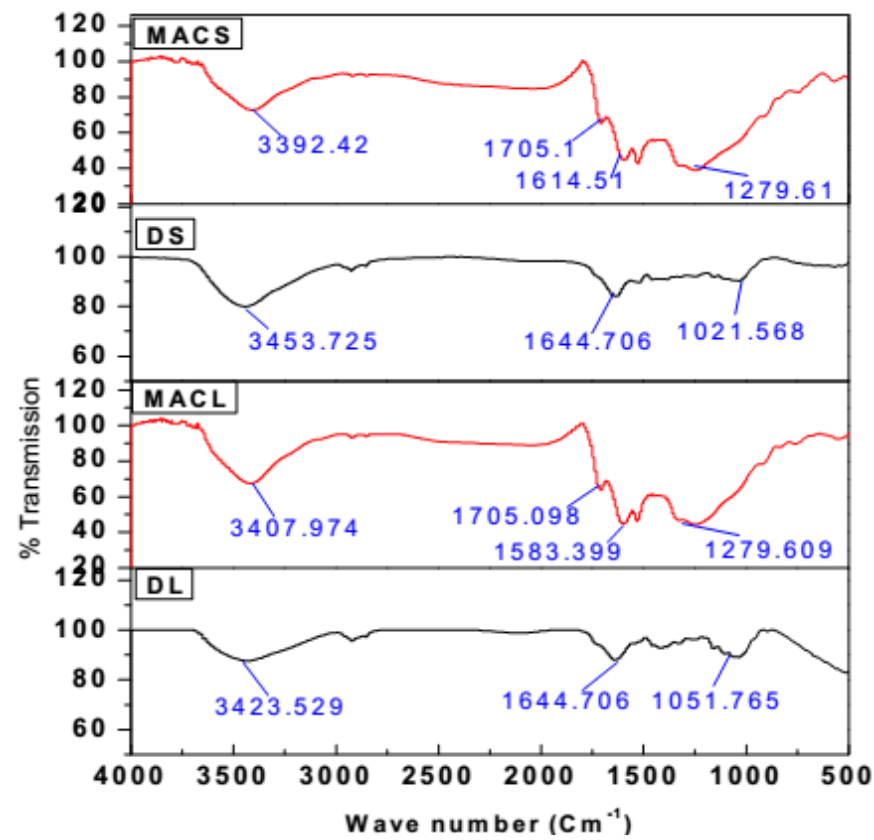

Figure 3: FTIR spectrum of dried Water hyacinth (stems and leaves), and nitric acid modified activated carbon 


\section{Adsorption parameters}

\section{Effect of $\mathrm{pH}$ on $\mathrm{Hg}^{2+}$ adsorption}

To study the influence of $\mathrm{pH}$ of solution on mercury sorption by DS, DL, MACS, and MACL, pH was varied from 1 to 5.5 as shown in Fig.4. The experiments were conducted with an initial metal concentration of $50 \mathrm{mg} / \mathrm{L}$ and the biomass concentration of $1 \mathrm{~g} / \mathrm{L}$ at $25 \mathrm{C}$. When the $\mathrm{pH}$ increases from $\mathrm{pH}=1$ to $\mathrm{pH}=5$, The amount of $\mathrm{Hg}^{2+}$ adsorbed at equilibrium (qe) increase from 13.74 to $38.2 \mathrm{mg} / \mathrm{g}$, from 12.7 to $43.46 \mathrm{mg} / \mathrm{g}$, from 7.96 to $44.76 \mathrm{mg} / \mathrm{g}$ and from 10.2 to $43.06 \mathrm{mg} / \mathrm{g}$ for DS, DL, MACL and MACS, respectively. The highest bio-sorption efficiency was observed at $\mathrm{pH}$ of 5 . In fact, $\mathrm{pH}$ dependency of the adsorption of aqueous mercury can be described by at least two mechanisms.

1. The first mechanism is the effect of $\mathrm{pH}$ on dissociation of acidic and basic surface functional groups as well as the effect on mercury species. It is reported that the most dominant mercury species at $\mathrm{pH}<3$ and $\mathrm{pH}>5$ are $\mathrm{Hg}^{2+}$ and $\mathrm{Hg}(\mathrm{OH})_{2}$, respectively (Shin \&Bae, 2009). In the presence of chloride and $\mathrm{pH}$ range between 4 and $6, \mathrm{HgCl}_{2}, \mathrm{Hg}(\mathrm{OH})^{+}$, $\mathrm{Hg}\left(\mathrm{Cl}_{2}\right)_{2}, \mathrm{Hg}(\mathrm{Cl})^{+}$, can slightly from these cationic complexes in aqueous solutions. At different solution $\mathrm{pH}$ values, surface charge of activated carbon can be changed due to the protonation or hydroxylation of surface functional groups. Hence, different mercury species with different charges can bind to adsorption sites on the activated carbon at each different $\mathrm{pH}$ of the solution. Especially at low $\mathrm{pH}$ values, surface of activated carbon is positively charged which has adverse effect on the adsorption of mercury cations such as $\mathrm{Hg}^{2+}, \mathrm{Hg}(\mathrm{Cl})^{+}$and $\mathrm{Hg}(\mathrm{OH})^{+}($Carrottetel, 1998).

2. The second mechanism is the competition of mercury species and protons for being bound on the adsorption sites of activated carbon at low $\mathrm{pH}$ amounts (Sahooetel, 1992). In fact, at very low $\mathrm{pH}$ amounts, concentration of $\mathrm{H}^{+}$is high enough to compete with mercury species for being adsorbed in the activated carbon. As $\mathrm{pH}$ increases, the negative charge density on the adsorbent surface increases due to deprotonation of active sites thus the approach of positively charged ions is promoted

At $\mathrm{pH}$ values $(\mathrm{pH}>5)$, the solubility of mercury decreases due to extensive hydrolysis (the percentage of $\mathrm{HgClOH}$ and $\mathrm{Hg}(\mathrm{OH})_{2}$ species increases) so to avoid precipitation of $\mathrm{Hg}$ (II) ions, all the following experiments were conducted at $\mathrm{pH}=5.0$.
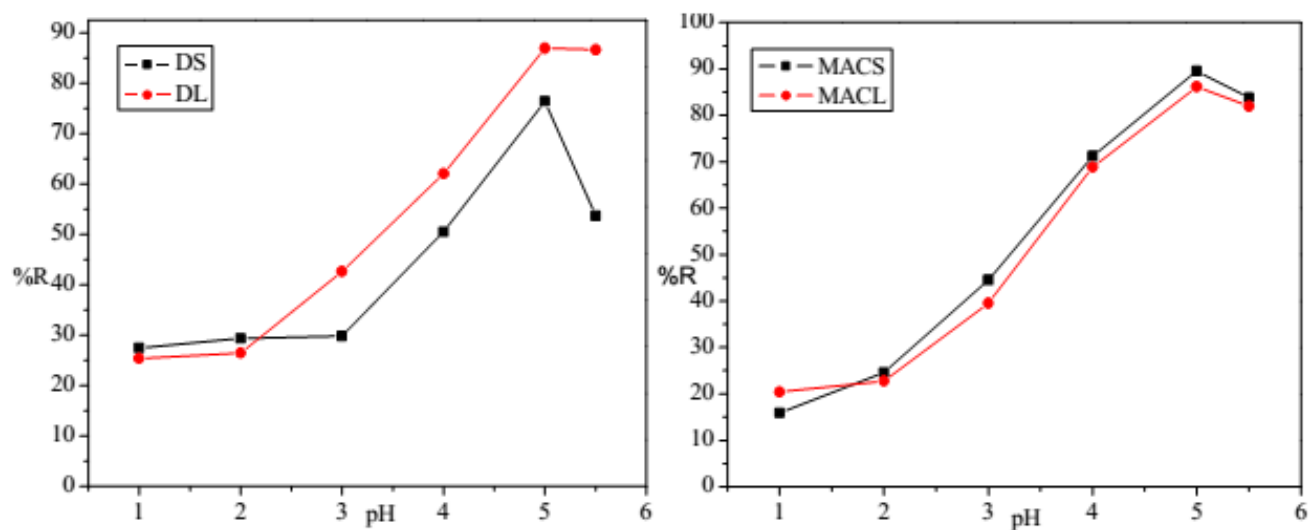

Figure 4: Effect of the $\mathrm{pH}$ values on adsorption capacity of $\mathrm{Hg}^{2+}$ by DS, DL, MACS and MACL (Conditions: $C_{o}=50 \mathrm{mg} / \mathrm{l}, \mathrm{T}=25^{\circ} \mathrm{C}$; adsorbent dose $=0.025 \mathrm{~g} / 25 \mathrm{ml}$ ). 


\section{Effect of initial concentration on the uptake of $\mathrm{Hg} 2+$}

The effect of initial $\mathrm{Hg}$ (II) concentration on the equilibrium uptake capacity is shown in Fig. 5. From the figure, it is evident that, when the initial concentration of $\mathrm{Hg}$ (II) increases from 10 to $500 \mathrm{mg} / 1$ at $25^{\circ} \mathrm{C}$, The amount of $\mathrm{Hg}$ (II) adsorbed at equilibrium (q $\mathrm{q}_{\mathrm{e}}$ ) increase from 7.96 to $41.7 \mathrm{mg} / \mathrm{g}$, from 9.6 to $57.59 \mathrm{mg} / \mathrm{g}$, from 9.95 to $102.6 \mathrm{mg} / \mathrm{g}$, and from 9.95 to $81.9 \mathrm{mg} / \mathrm{g}$ for DS, DL, MACS and MACL, respectively. Apparently, the initial $\mathrm{Hg}$ (II) concentration plays an important role in affecting the capacity of $\mathrm{Hg}$ (II) to adsorb onto different adsorbents. The amount of the $\mathrm{Hg}$ (II) adsorbed onto DS, DL , MACS , and MACL increases with an increase in the initial $\mathrm{Hg}$ (II) concentration at a constant amount of adsorbent. This may be attributed to the fact that, the higher the $\mathrm{Hg}$ (II) concentration is, the stronger the driving force of the concentration gradient thus the higher the adsorption capacity. The $C_{o}$ provides the necessary driving force to overcome the resistances to the mass transfer of $\mathrm{Hg}$ (II) between the aqueous and the solid phases. The increase in $\mathrm{C}_{0}$ also enhances the interaction between $\mathrm{Hg}$ (II) and MACS, MACL, DS, and DL adsorbents. Therefore, an increase in $\mathrm{C}_{\mathrm{o}}$ of $\mathrm{Hg}$ (II) enhances the adsorption uptake of the $\mathrm{Hg}$ (II).

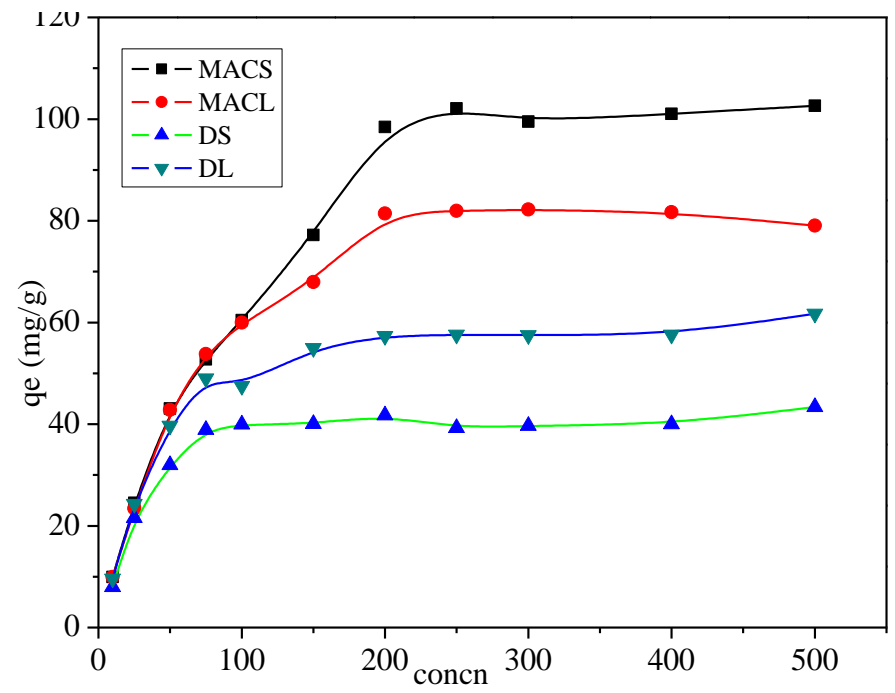

Figure 5: Effect of initial metal concentration on the removal of $\mathrm{Hg} 2+$ by $\mathrm{DL}, \mathrm{DS}, \mathrm{MACL}$ and MACS. (Conditions: $C_{o}=5-500 \mathrm{mg} / \mathrm{l}, \mathrm{T}=25^{\circ} \mathrm{C}$; adsorbent dose $=0.025 \mathrm{~g} / 25 \mathrm{ml}$ ).

\section{Effect of temperature on adsorption}

To study the influence of the temperature on mercury adsorption by DS, DL, MACS, and MACL adsorbents, temperature was varied from $25^{\circ} \mathrm{C}$ to $50{ }^{\circ} \mathrm{C}$ as shown in Fig. 6. The experiments were conducted within an initial concentration range $(50-500 \mathrm{mg} / \mathrm{l})$ and biomass concentration of $1 \mathrm{~g} / 1 \mathrm{pH}$ 5.0. Table 23.shows that When the temperature increased from $25{ }^{\circ} \mathrm{C}$ to $50{ }^{\circ} \mathrm{C}$, the maximum adsorption capacities of $\mathrm{Hg}^{2+}$ removed by DS, DL, MACL and MACS are found to be increased from 41.7 to $83.7 \mathrm{mg} / \mathrm{g}$, from 57.59 to $104 \mathrm{mg} / \mathrm{g}$, from 81.9 to $132.4 \mathrm{mg} / \mathrm{g}$ and from 102.6 to $135 \mathrm{mg} / \mathrm{g}$, respectively. In fact, the temperature has two main effects on the adsorption processes of the porous adsorbents. It can affect the diffusion rate of the sorbate within the pores as a result of decreasing solution viscosity and the number of the sorption sites generated because of breaking of some internal bonds near the edge of active surface sites of sorbent, which benefits for improving the adsorption capacity of the adsorbents (Boudrahemetel, 2009). 
The results indicate that the adsorption reaction of $\mathrm{Hg}(\mathrm{II})$ ions adsorbed by DS, DL, MACS, and MACL adsorbents increase with an increase in temperature, which indicate the process to be endothermic. The increase in mercury removal with an increase in temperature may be due to the increased chemical interactions between mercury ions and the functional groups on the surface of the activated carbon surface, which indicates the process to be chemisorption. In other words, increasing temperature can increase the diffusion rate of $\mathrm{Hg}$ (II) ions and the number of the sorption sites and thus enhance the adsorption ability of prepared activated carbon.

If notice to the obtained results, it is obvious that the adsorption of the Mercury increases in the order of MACS > MACL > DS > DL under all conditions studied such as concentration, temperature and $\mathrm{pH}$. This behavior is attributed to the increase in the surface area of adsorbent and increase in the number of active sites (functional groups) on the surface of adsorbents.

Table 2: Effect of temperature on maximum adsorption capacities of $\mathrm{Hg}^{2+}$ by $\mathrm{DS}, \mathrm{DL}, \mathrm{MACS}$ and MACL

\begin{tabular}{|c|c|c|c|}
\hline \multirow{2}{*}{ Samples } & \multicolumn{3}{|c|}{$Q_{e}\left(\mathrm{mg} \mathrm{g}^{-1}\right)$} \\
\cline { 2 - 4 } & $25^{\circ} \mathrm{C}$ & $40^{\circ} \mathrm{C}$ & $50^{\circ} \mathrm{C}$ \\
\hline$D S$ & 41.7 & 55.5 & 83.7 \\
\hline$D L$ & 57.59 & 84.8 & 104 \\
\hline$M A C S$ & 102.6 & 125.13 & 135 \\
\hline$M A C L$ & 81.9 & 113.08 & 132.4 \\
\hline
\end{tabular}
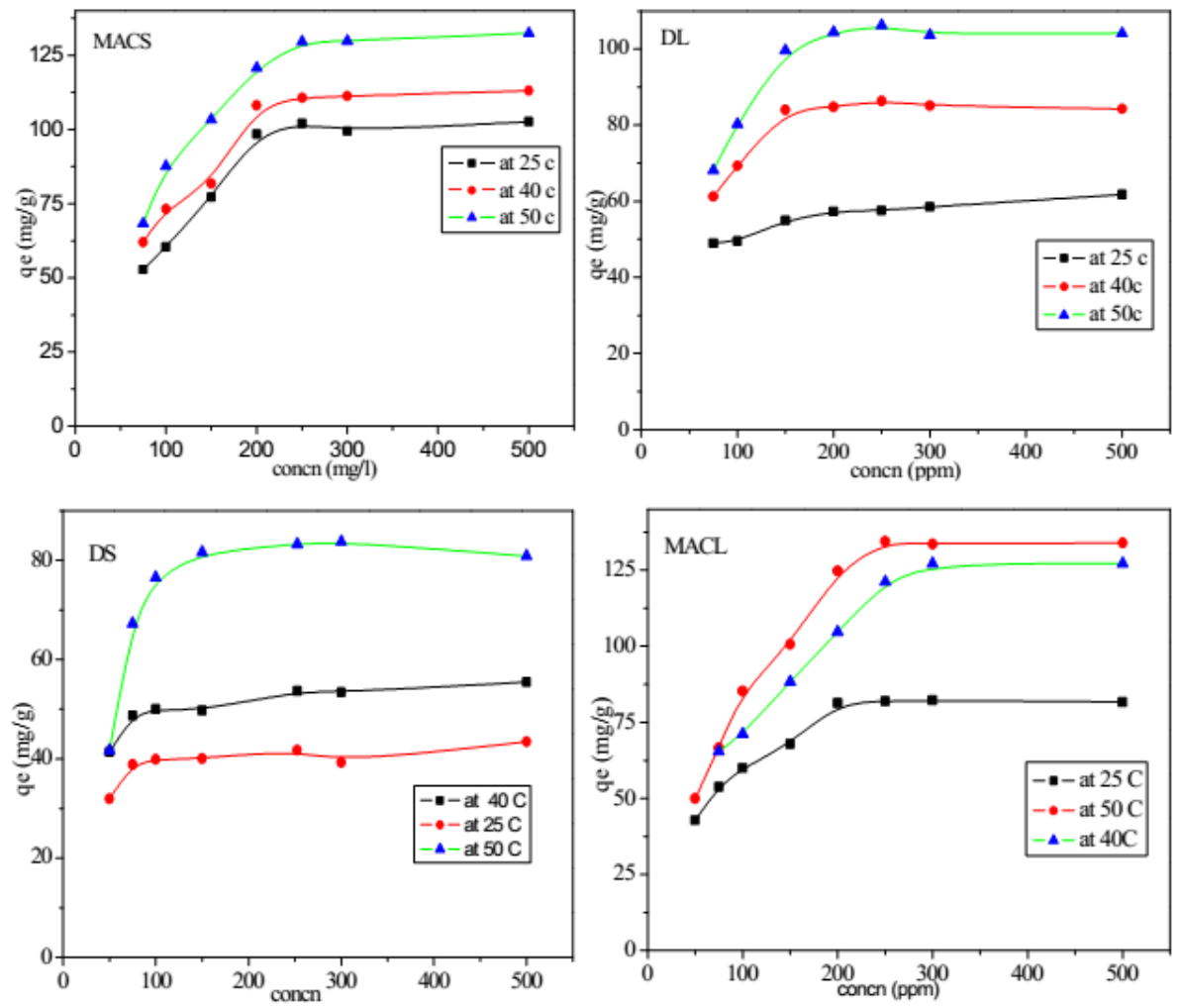

Figure 6: Effect of temperature on adsorption capacity of $\mathrm{Hg}^{2+}$ by DS, DL, MACS and MACL. (Conditions: $\mathrm{C}_{o}=50-500 \mathrm{ppm}$; adsorbent dose $=0.025 \mathrm{~g} / 25 \mathrm{ml} ; \mathrm{pH}=5$ ). 


\section{Effect of ionic strength}

Fig.7. presents the effect of ionic strength on the uptake of $\mathrm{Hg}^{2+}$ ions. It was observed that the adsorption capacity decreased with the increase in ionic strength. As the concentration of $\mathrm{NaCl}$ ions increased from 0.05 to $0.5 \mathrm{M}$, the removal efficiency $(\% \mathrm{E})$ of Mercury decreased from 62.04 $\%$ to $42.4 \%$, from $78.7 \%$ to $42.4 \%$, from $93.9 \%$ to $34.5 \%$ and from $\% 91.9$ to $30.04 \%$ for DS, DL, MACS and MACL, respectively. This may be attributed to competition between cations $\left(\mathrm{Na}^{+}\right.$ ions) and $\mathrm{Hg}$ (II) for the active sites on the adsorbent surface.As well as, increasing chloride ion concentration considerably decrease the adsorption of mercury by adsorbents due to the formation of more stable $\mathrm{Hg}-\mathrm{Cl}$ complexes which are poorly adsorbed.
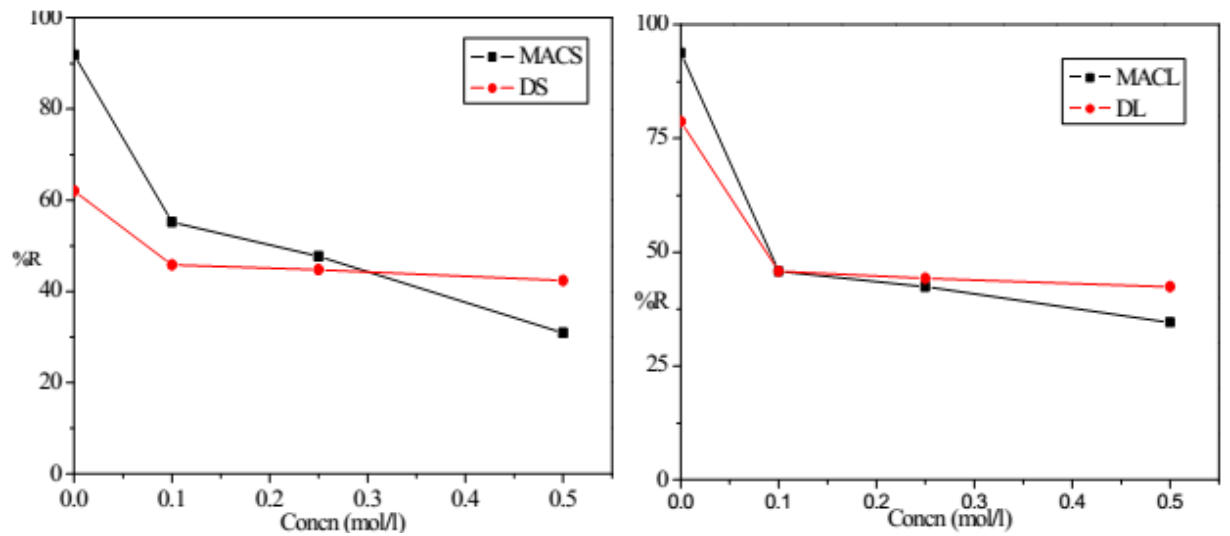

Figure 7: Effect of ionic strength on the removal of $\mathrm{Hg}^{2+}$ by DS, DL, MACS and MACL. (Conditions: $\mathrm{T}=25^{\circ} \mathrm{C}$; adsorbent dose $=0.025 \mathrm{~g} / 25 \mathrm{ml} ; \mathrm{C}_{0}=50 \mathrm{mg} / \mathrm{l}$; time $=7 \mathrm{~h}$ ).

\section{Effect of contact time}

The relationship between contact time and $\mathrm{Hg}$ (II) sorption onto DS, DL, MACS, and MACL at initial Hg (II) concentration of $250 \mathrm{ppm}$ is shown in Fig.8. The results revealed that the uptake of sorbate species is fast at the initial stages of the contact period and a large fraction of the total amount of metal was removed within a few minutes more than $67 \%, 56 \%, 63 \%$, and $84.4 \%$ of the adsorption capacities of corresponding adsorbents for $\mathrm{Hg}$ (II) occurred within 5 min for MACL, DL, MACS, and DS, respectively. Thereafter, it becomes slower near the equilibrium and the maximum removal of $\mathrm{Hg}$ (II) occurred within $45-60 \mathrm{~min}$ at which the rate of sorption is found to be nearly constant. This is obvious by the fact that a large number of vacant surface sites are available for sorption during the initial stage, and after a lapse of time, the remaining vacant surface sites are difficult to be occupied due to repulsive forces between the solute ions on the solid and the bulk phases.After $1 \mathrm{~h}$, the uptake was almost constant such that it could be considered the equilibrium time of the $\mathrm{Hg}$ (II) adsorption. To ensure that sufficient contact time was obtained, further adsorption experiments were carried out for $7 \mathrm{~h}$. 

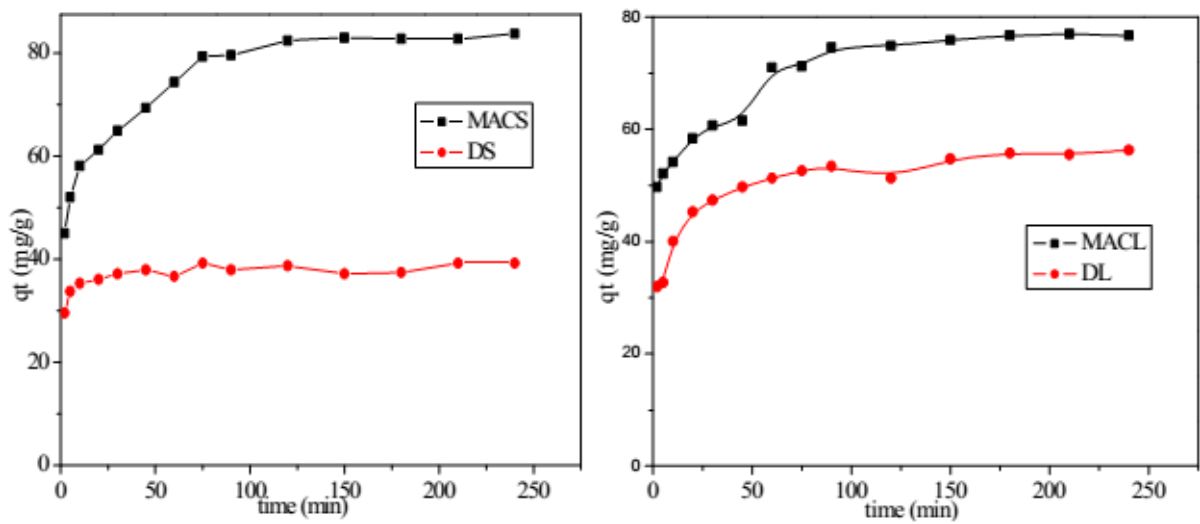

Figure 8: Effect of contact time on adsorption capacity of $\mathrm{Hg}^{2+}$ by DS, DL, MACS and MACL. (Conditions: $C_{o}=250 \mathrm{mg} / \mathrm{l}, \mathrm{T}=25^{\circ} \mathrm{C}$; adsorbent dose $=0.1 \mathrm{~g} / 100 \mathrm{ml}$ ).

\section{Effect of adsorbent dosage}

The effect of bio sorbent dosage on the removal of $\mathrm{Hg}$ (II) is shown in Fig.9. As seen in this figure, percentage removal of $\mathrm{Hg}$ (II) increase with increase in bio sorbent dosage from 0.4 to $4 \mathrm{~g} / 1$., The percent of mercury removal by DS, DL, MACS and MACL increase from $37.43 \%$ to $79.58 \%$, from $32.59 \%$ to $78.27 \%$, from $41.49 \%$ to $82.33 \%$ and from $28.66 \%$ to $87.17 \%$, respectively. There is no significant increase in removal of $\mathrm{Hg}$ (II) when bio sorbent dosage increases beyond $4 \mathrm{~g} / \mathrm{l}$. This suggests that after a certain bio sorbent dosage, the maximum bio sorption is attained and hence the amount of ions remains constant even with further increase in the surface area of the bio sorbent, which in turn increases the number of binding sites. However, at high sorbent dosages the available metal ions are insufficient to cover all the exchangeable sites on the bio-sorbent, resulting in low metal uptake (Gong etel, 2005). Therefore, the optimum dosage for dried water hyacinth and activated carbon developed from it is $4 \mathrm{~g} / 1 \mathrm{but} 1 \mathrm{~g} / 1$ dosage is used for all further experiments.
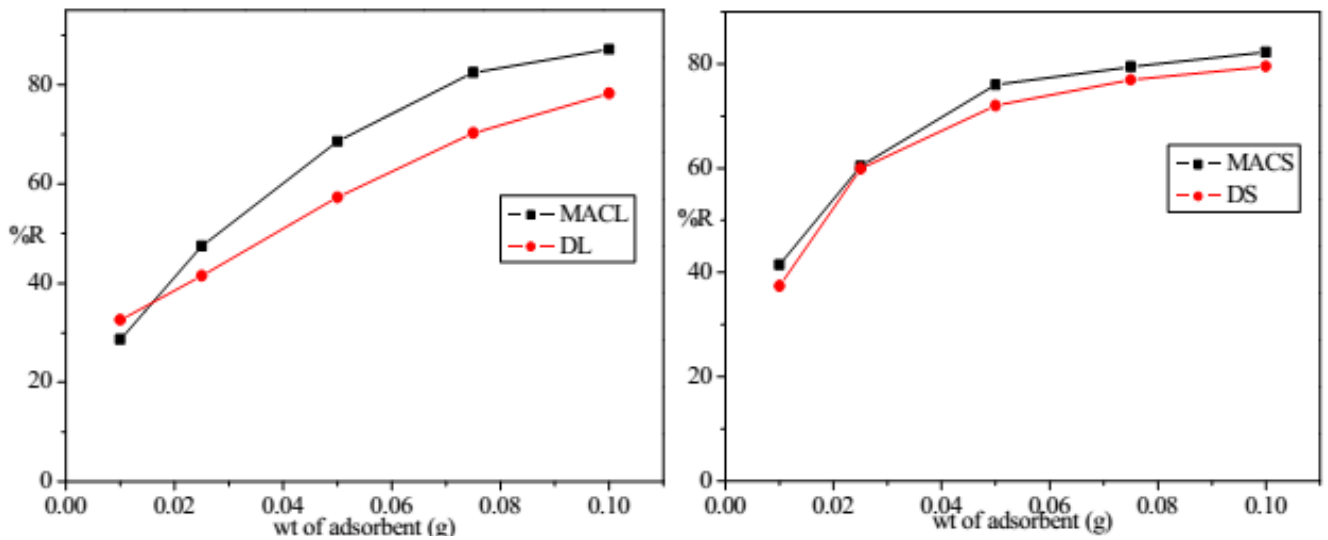

Figure 9: Effect of sorbent dosage on the removal of $\mathrm{Hg}^{2+}$ by DS, DL, MACS and MACL. (Conditions: $\mathrm{T}=25^{\circ} \mathrm{C} ; \mathrm{C}_{o}=100 \mathrm{mg} / \mathrm{l}, \mathrm{v}=25 \mathrm{ml}$; time $=7 \mathrm{~h}, \mathrm{pH}=5$ ) 


\section{Adsorption isotherms}

The experimental adsorption equilibrium data were analyzed in terms of Langmuir and Freundlich isotherm models which can be expressed:

$$
\begin{array}{ll}
\text { Freundlich isotherm: } & \ln q_{e}=\ln K_{f}+\frac{1}{n} \ln C_{e} \\
\text { Langmuir isotherm: } & \frac{C_{e}}{q_{e}}=\frac{1}{Q b}+\frac{C_{e}}{Q}
\end{array}
$$

Where $\mathrm{q}_{\mathrm{e}}$ is the amount adsorbed at equilibrium $\left(\mathrm{mg} \mathrm{g}^{-1}\right), \mathrm{C}_{\mathrm{e}}$ is the equilibrium concentration of the $\mathrm{Hg}$ (II) $\left(\mathrm{mg} \mathrm{L}^{-1}\right)$, constant $\mathrm{b}$ is related to the energy of adsorption $\left(\mathrm{Lmg}^{-1}\right), \mathrm{Q}_{\mathrm{o}}$ is the Langmuir monolayer adsorption capacity $\left(\mathrm{mg} \mathrm{g}^{-1}\right), \mathrm{K}_{\mathrm{f}}$ is roughly an indicator of the adsorption capacity, and $1 / \mathrm{n}$ is the adsorption intensity. Langmuir and Freundlich isotherms for adsorption of $\mathrm{Hg}$ (II) onto DS, DL, MACS and MACL at different initial concentrations are given in Figs. 10, 11, respectively. Tables 24, 25, summarize the Langmuir and Freundlich constants the calculated coefficients. It can be found that the regression coefficient $\mathrm{R}^{2}$ obtained from Langmuir model is much higher than that from Freundlich model, suggesting that the Langmuir isotherm fits better with the experimental data. The maximum monolayer adsorption capacity(Qmax) of $\mathrm{Hg}$ (II) by MACS, MACL, DS and DL at $25^{\circ} \mathrm{C}$ was calculated to be 105.7, 81.9, 41.1 and $58.5 \mathrm{mg} \mathrm{g}^{-1}$ are all the same as the experimental data. The essential characteristics of the Langmuir isotherm can also be expressed in terms of a dimensionless constant separation factor or equilibrium parameters, RL, which is defined as (Pavanetel, 2008)

$$
R l=\frac{1}{1+b c_{0}}
$$

Where $b\left(\mathrm{Lmg}^{-1}\right)$ is the Langmuir constant and $\mathrm{C}_{0}\left(\mathrm{mg} \mathrm{L}^{-1}\right)$ is the initial concentration in the liquid phase. The value of $\mathrm{R}_{\mathrm{L}}$ indicates the shape of the isotherm.

\begin{tabular}{|c|c|}
\hline$R L$ value & Type of isotherm \\
\hline$R L>1$ & Un favorable \\
\hline $0<R L<1$ & favorable \\
\hline$R L=1$ & Linear \\
\hline$R L=0$ & irreversible \\
\hline
\end{tabular}

For $\mathrm{Hg}$ (II) adsorption on MACS, MACL, DS and DL, $\mathrm{R}_{\mathrm{L}}$ values obtained are in the range between 0 and 1 , thereby confirming that the adsorption is a favorable process.

Table 3: Parameters of langmuir isotherm for adsorption of $\mathrm{Hg}^{2+}$ by DS, DL, MACS and MACL.

\begin{tabular}{|c|c|c|c|c|c|}
\hline \multirow{2}{*}{ Adsorbents } & \multicolumn{5}{|c|}{ Langmuir parameters } \\
\cline { 2 - 6 } & $R^{2}$ & $b(\mathrm{~L} / \mathrm{mg})$ & $Q_{\max , \text { fitted }}$ & $Q_{\exp }$ & $R_{L}$ \\
\hline MACS & 0.994 & 0.0775 & 105.7 & 102.6 & 0.025 \\
\hline MACL & 0.997 & 0.1588 & 81.9 & 81.9 & 0.0124 \\
\hline$D S$ & 0.997 & 0.258 & 41.1 & 41.7 & 0.086 \\
\hline$D L$ & 0.997 & 0.2164 & 58.5 & 57.59 & 0.0181 \\
\hline
\end{tabular}

Table 4: Parameters of Freundlich isotherm for adsorption of $\mathrm{Hg}^{2+}$ by DS, DL, MACS and MACL.

\begin{tabular}{|c|c|c|c|}
\hline \multirow{2}{*}{ Adsorbents } & \multicolumn{3}{|c|}{ Freundlich parameters } \\
\cline { 2 - 4 } & $R^{2}$ & $K f$ & $1 / n$ \\
\hline MACS & 0.919 & 24.95 & 0.263 \\
\hline MACL & 0.948 & 30.33 & 0.185 \\
\hline$D S$ & 0.0 .633 & 28.05 & 0.074 \\
\hline$D L$ & 0.909 & 31.32 & 0.115 \\
\hline
\end{tabular}




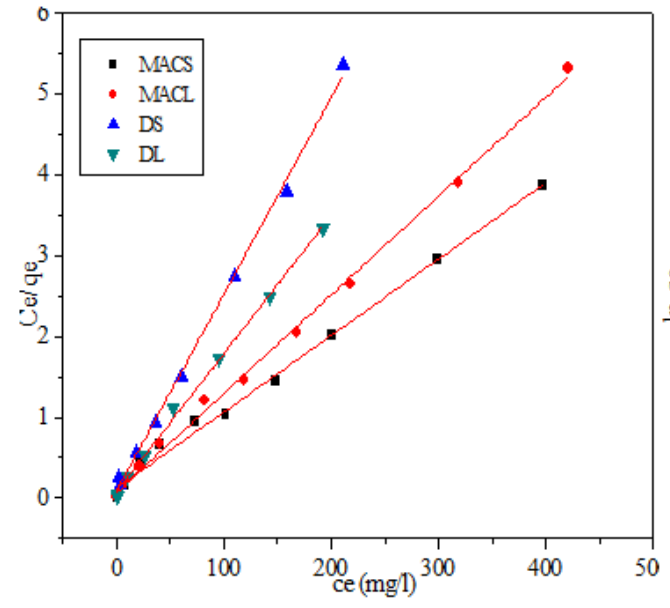

Figure 10: Langmuir plot for the adsorption of $\mathrm{Hg}^{2+}$ by $\mathrm{DS}$, DL MACS and MACL

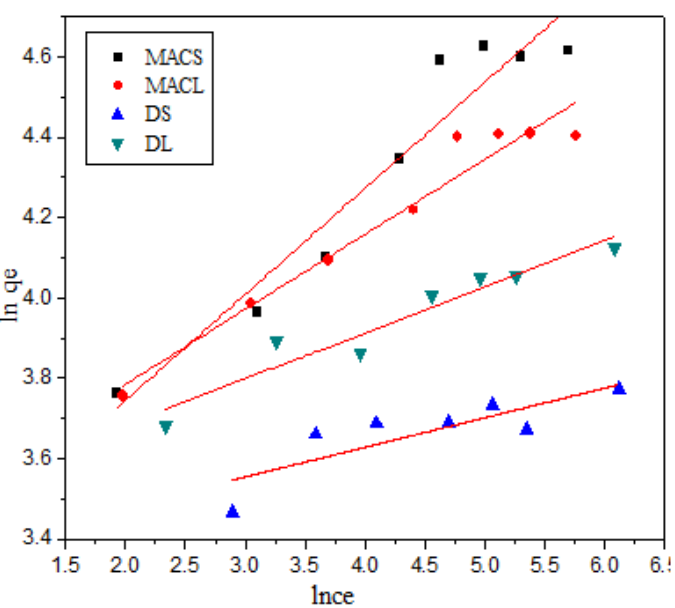

Figure 11: Freundlich plot for adsorption of $\mathrm{Hg}^{2+}$ by DS, DL MACS and MACL

\section{Adsorption Kinetics}

To study the mechanism of the adsorption process steps, such as the mass transport and chemical reaction processes, kinetic models were used to test the experimental data. The kinetics of $\mathrm{Hg}$ (II) adsorption on the modified water hyacinth activated carbon and dried water hyacinth were analyzed using pseudo-first-order, pseudo-second-order, and intra particle diffusion models.

The pseudo-first-order kinetic model is expressed as follow (Webi \& Chakravort, 1974):

$\log \left(q_{e}-q_{t}\right)=\log \dot{q}_{e}-\frac{K_{1} t}{2.303}$

Where qe and qt are the amounts of mercury adsorbed $\left(\mathrm{mg} \mathrm{g}^{-1}\right)$ at equilibrium and at time $\mathrm{t}(\mathrm{min})$, respectively, and $\mathrm{k}_{1}$ the rate constant of adsorption $\left(\mathrm{min}^{-1}\right)$. Values of $\mathrm{k}_{1}$ were calculated from the plots of $\ln \left(\mathrm{q}_{\mathrm{e}}-\mathrm{q}_{\mathrm{t}}\right)$ versus $\mathrm{t}$ (fig.12) at initial concentration of $250 \mathrm{ppm}$ of mercury. The correlation coefficient values $\mathrm{R}^{2}$ are low, the experimental qe values do not agree with the calculated ones, obtained from the linear plots (Table 5). This shows that the adsorption of cadmium on MACS, MACL, DS and DL is not a first-order reaction.

The second-order kinetic model is expressed as:

$\frac{t}{q_{t}}=\frac{1}{K_{2} q_{e}^{2}}+\frac{t}{q_{e}}$

Where $\mathrm{k}_{2}$ is the rate constant of second-order adsorption $\left(\mathrm{g} \mathrm{mg}^{-1} \mathrm{~min}^{-1}\right)$. If the second-order kinetics is applicable, then the plot of $t / q_{t}$ versus $t$ should show a linear relationship. Values of $k_{2}$ and $q_{e}$ were calculated from the intercept and slope of the plots of $t / q_{t}$ versus $t$. The linear plots of $t / q_{t}$ versus $t$ (Fig. 13) show a good agreement between experimental and calculated $\mathrm{q}_{\mathrm{e}}$ values (Table 6). The correlation coefficients for the second-order kinetic model are greater than 0.99 indicating that the adsorption system is probably best described by the pseudo second kinetic model. Moreover, the calculated adsorption capacities determined using pseudo-second-order plots are in good agreement with the experimental values. This fact confirms the earlier hypothesis that the adsorption of mercury by DS, DL, MACS, and MACL is controlled by chemisorption. 

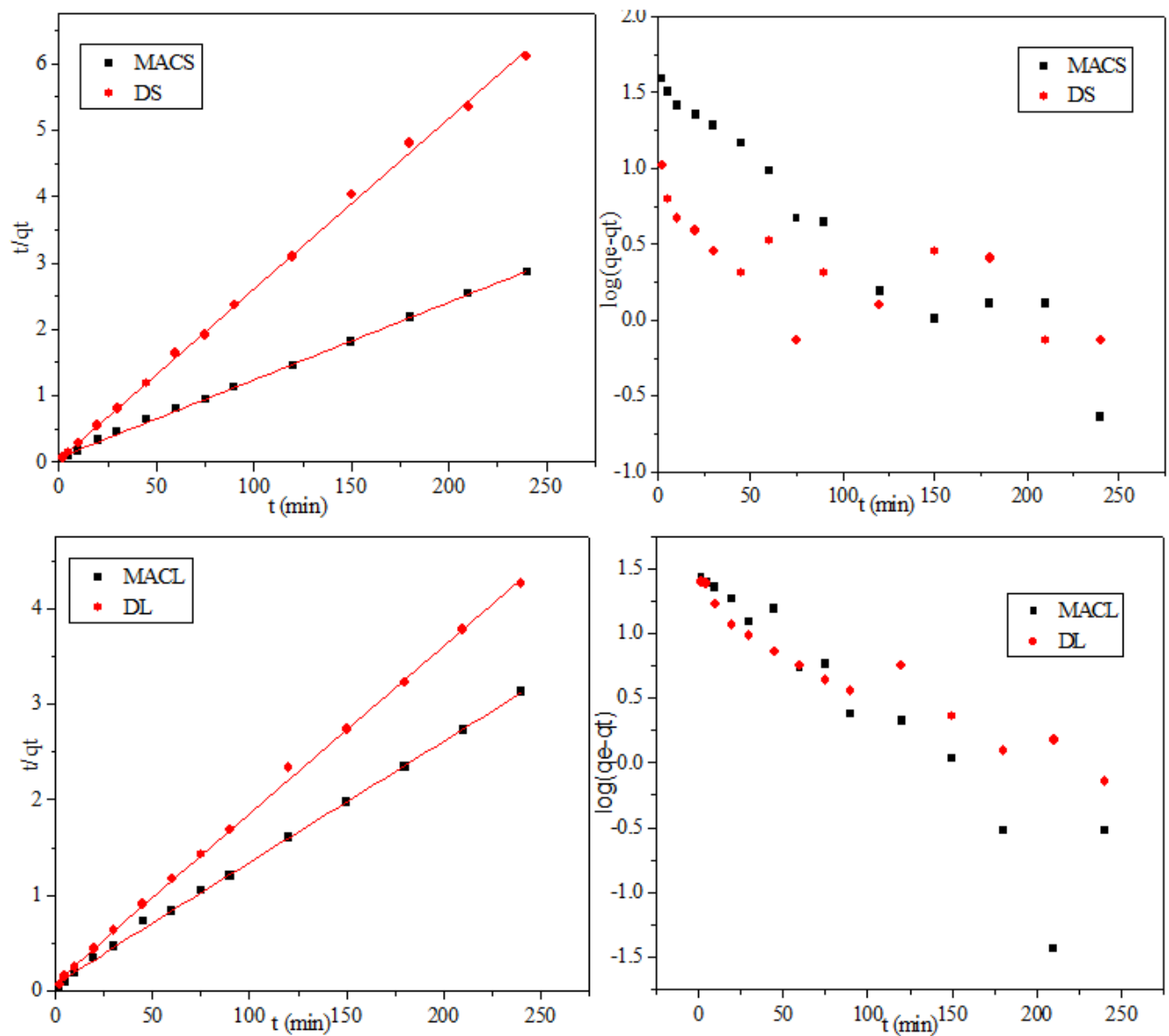

Figure 12: Pseudo-second-order kinetic model for the adsorption of $\mathrm{Hg}^{2+}$ by $D S, D L, M A C S$ and $M A C L$

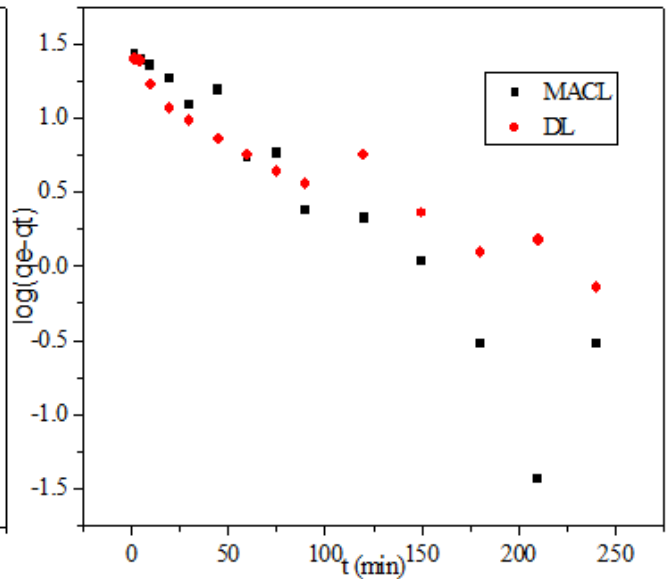

Figure 13: Psendo-first-order model for the adsorption of $\mathrm{Hg}^{2+}$ by $D S, D L, M A C S$ and $M A C L$

Table 5: Parameters of first order kinetic model for adsorption of $250 \mathrm{ppm} \mathrm{Hg}^{2+}$ by DS, DL, MACS and MACL.

\begin{tabular}{|c|c|c|c|c|}
\hline \multirow{2}{*}{ Adsorbent Code } & \multicolumn{4}{|c|}{ Pseudo-first order } \\
\cline { 2 - 5 } & qe exp. $m g . g^{-1}$ & qe cal. $m g . g^{-1}$ & $K_{1}\left(\mathrm{~min}^{-1}\right)$ & $R^{2}$ \\
\hline MAC S & 84 & 30.9 & 0.019 & 0.9345 \\
\hline MACL & 77 & 29.5 & 0.024 & 0.904 \\
\hline DS & 40 & 4.6 & 0.0075 & 0.497 \\
\hline D L & 57 & 17.1 & 0.0133 & 0.914 \\
\hline
\end{tabular}

Table 6: Parameters of second order kinetic model for adsorption of $250 \mathrm{ppm} \mathrm{Hg}^{2+}$ by DS, DL, $M A C S$ and $M A C L$

\begin{tabular}{|c|c|c|c|c|}
\hline Adsorbent Code & qe exp. mg.g & qe cal. $m g \cdot g^{-1}$ & $\begin{array}{c}K_{2} \\
\text { g.mg-1 } \text { min }^{-1}\end{array}$ & $R^{2}$ \\
\hline MACS & 84 & 85.62 & 0.0019 & 0.999 \\
\hline$M A C L$ & 77 & 78.55 & 0.016 & 0.999 \\
\hline$D S$ & 40 & 38.91 & 0.0023 & 0.999 \\
\hline$D L$ & 57 & 56.8 & 0.0033 & 0.999 \\
\hline
\end{tabular}

Intra particle diffusion model 
The kinetic results were analyzed by the intra-particle diffusion model to elucidate the diffusion mechanism by Weber and Morris equation. The linear form of intra-particle diffusion model was given by (Boyd, 1947):

$\mathrm{q}_{\mathrm{t}}=\mathrm{K}_{\mathrm{d}} \mathrm{t}^{0.5}+\mathrm{C}$

Where $C$ was the intercept and $K_{d}$ was the intra-particle diffusion rate constant (mg g-1 $\left.\min ^{-0.5}\right)$. According to this model, plot of $q_{t}$ versus $\mathrm{t}^{1 / 2}$ should be linear if intra-particle diffusion was involved in the adsorption process. If these lines passed through the origin, then intra-particle diffusion was the rate controlling step. When these lines did not pass through the origin, this was indicative of some degree of boundary layer control and this further showed that the intra-particle diffusion was not the only rate-limiting step. The values of $K_{d}$ were given in Table 7.

In this experiment, the plots did not pass through the origin (fig.14), which indicated the intra particle diffusion was not only the rate controlling step. The boundary layer effect (film diffusion) may control the rate of mass transfer in the time period of the first linear segment; this conclusion could be corroborated by the analysis of data from Boyd's model.

The model of Boyd is expressed as (Reichenberg, 1953):

$F=1-\frac{6}{\exp }\left(1-B_{t}\right)$

п 2

Where $F$ is the fractional attainment of equilibrium, at different times, $t$, and $B_{t}$ is a function of $\mathrm{F}$

$F=\frac{q_{t}}{q_{e}}(10)$

Where $\mathrm{q}_{\mathrm{t}}$ and $\mathrm{q}_{\mathrm{e}}$ are the metal uptake $\left(\mathrm{mmol} \mathrm{g}^{-1}\right)$ at time $\mathrm{t}$ and at equilibrium, respectively.

Eq. (6) can be rearranged to

$B_{t=}-0.4977-\ln (1-F)$

From Boyd plot, (Fig.15) it was observed that the plots are linear but do not pass though the origin suggesting that the adsorption process is controlled by film diffusion. However, The Boyd intercept values are greater than 0.5 for all adsorbents indicating that intraparticle diffusion along with film diffusion controls the adsorption of $\mathrm{Hg}^{2+}$ on all adsorbents. 

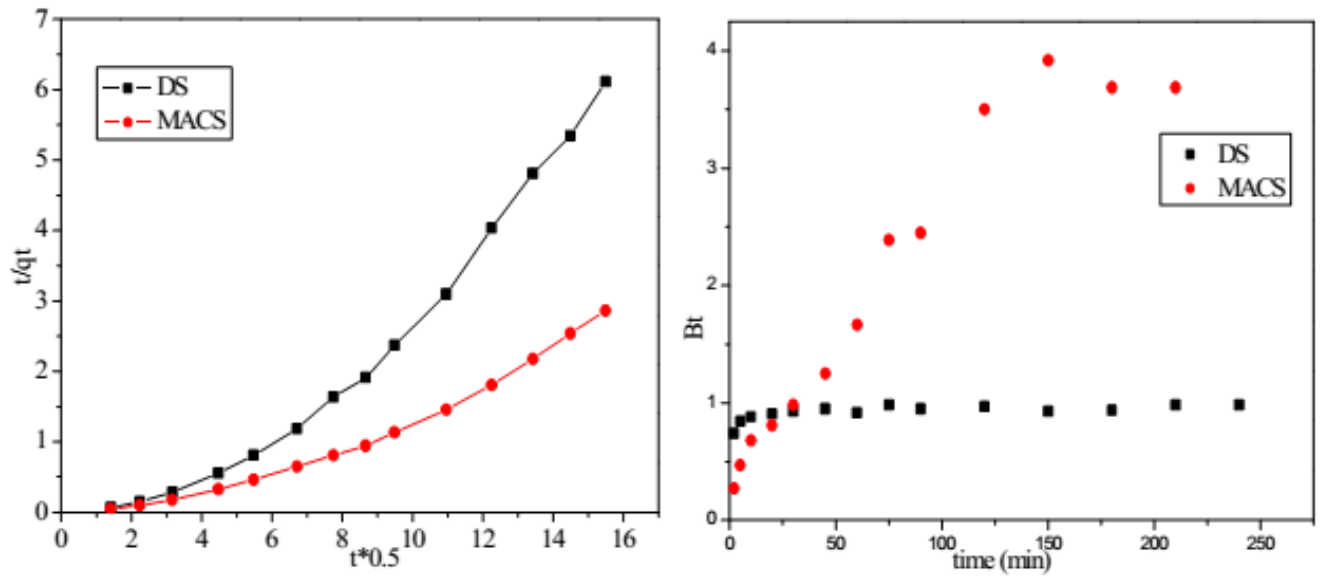

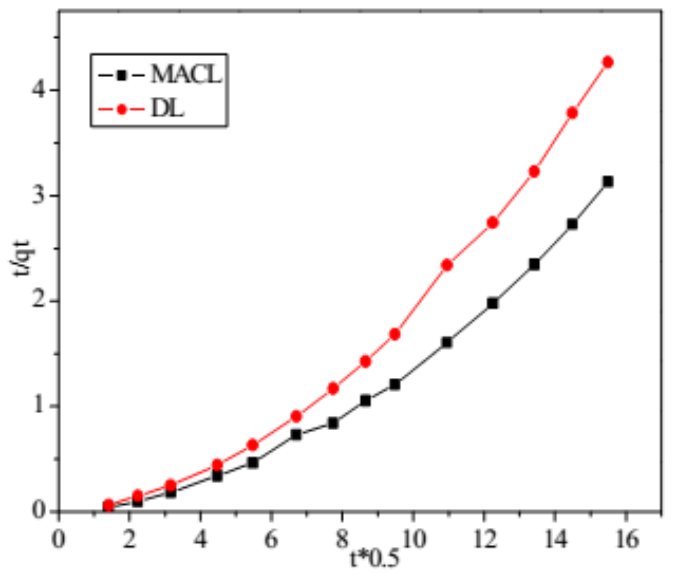

Figure 15: Bt versus t plot for adsorption of $\mathrm{Hg}^{2+}$ on DS, $D L, M A C S$ and $M A C L$ at $250 \mathrm{ppm}$

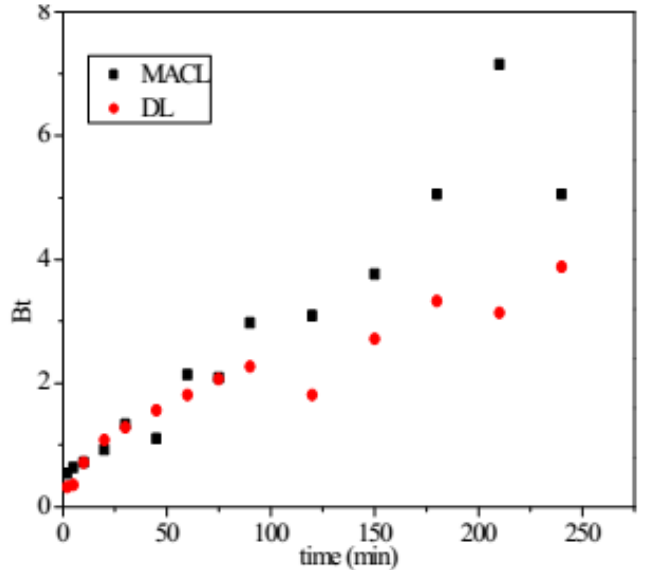

Figure 14: Intra-particle diffusion plots for adsorption of $\mathrm{Hg}^{2+}$ on $D S, D L$, and $M A C L$ at $250 \mathrm{ppm}$.

Table 8: Intra-particle diffusion parameters for adsorption of $\mathrm{Hg}(\mathrm{II})$ by $\mathrm{DS}, \mathrm{DL}, \mathrm{MACS}$ and MACL at $250 \mathrm{ppm}$

\begin{tabular}{|c|c|c|c|c|c|}
\hline \multicolumn{4}{|c|}{ Intraparticle diffusion model } & \multicolumn{2}{c|}{ Boyd model } \\
\hline Adsorbent code & $R^{2}$ & Kd & Intercept & Intercept & $R^{2}$ \\
\hline MACS & 0.953 & 0.197 & -0.53 & 0.512 & 0.934 \\
\hline MACL & 0.953 & 0.215 & -0.58 & 0.467 & 0.904 \\
\hline$D S$ & 0.948 & 0.433 & -1.279 & 0.870 & 0.360 \\
\hline$D L$ & 0.954 & 0.297 & -0.818 & 0.708 & 0.914 \\
\hline
\end{tabular}

\section{Evaluation of thermodynamic parameters}

The temperature dependence of adsorption is associated with various thermodynamic parameters. To study the thermodynamics of adsorption, adsorption studies were performed at 25,40 , and $50 \mathrm{C}$. Thermodynamic parameters $\Delta H^{\circ}$ and $\Delta S^{\circ}$ were calculated from the Van't Hoff equation (Dural etel, 2011)]:

$\ln \mathrm{k}_{\mathrm{d}}=\frac{\Delta \mathrm{S}^{\circ}}{\mathrm{R}}-\frac{\Delta \mathrm{H}^{\circ}}{\mathrm{RT}}(12)$

$K d=\frac{q_{e}}{c_{e}} \times \rho$ 
Where $\mathrm{Kd}$ is the adsorption coefficient, $\rho=1000 \mathrm{~g} / \mathrm{L}$ to make a dimensionless $\mathrm{Kd}$. The plot of $l n k_{d}$ versus $1 / T$ was found to be linear as illustrated in Fig.16 .The values of $\Delta S^{\circ}$ and $\Delta \mathrm{H}^{\circ}$ were calculated from the intercept and slope of linear plot. The standard free energy change, $\Delta \mathrm{G}^{\circ}$, was calculated using the expression (Dural etel, 2011):

$\Delta \mathrm{G}^{\circ}=\Delta H^{\circ}-T \Delta S^{\circ}$

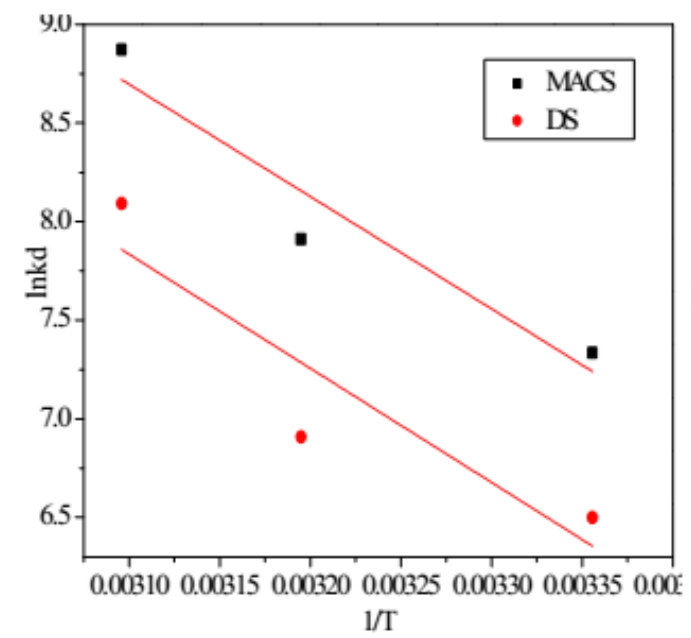

(14)

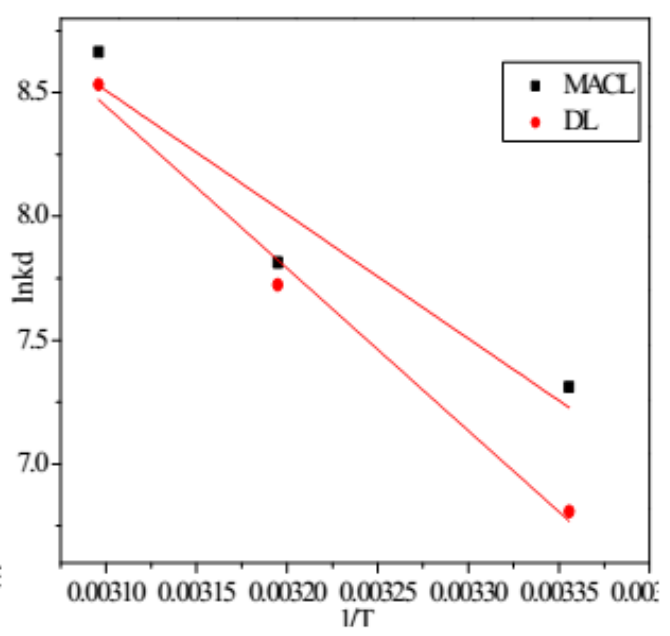

Figure 16: The plots of $\ln K d$ versus $T^{-1}$ for estimations of thermodynamic parameters of the adsorption process of $\mathrm{Hg}^{2+}$ by MACS, MACL, DS and DL. Condition : ( $\mathrm{C}_{0}=100 \mathrm{ppm}, \mathrm{T}=25-50$ ${ }^{0} \mathrm{C}, t=5 \mathrm{~h}$, adsorbent dose $=0.025 \mathrm{~g} / 25 \mathrm{ml}$ )

Table 9: Thermodynamic parameters for adsorption of $\mathrm{Hg}^{2+}$ by MACS, MACL, DS and DL at different temperatures.

\begin{tabular}{|c|c|c|c|c|c|c|}
\hline Adsorbents & $\begin{array}{c}\text { Mercury } \\
\text { concentration } \\
(\mathrm{mg} / \mathrm{L})\end{array}$ & $\Delta \mathrm{H}(\mathrm{kJ} / \mathrm{mol})$ & $\Delta \mathrm{S}(\mathrm{kJ} / \mathrm{mol})$ & \multicolumn{3}{|c|}{$\Delta \mathrm{G}(\mathrm{kJ} / \mathrm{mol})$} \\
\hline & & & & $298 \mathrm{~K}$ & $313 \mathrm{~K}$ & $323 \mathrm{~K}$ \\
\hline MAC S & 100 & 47.35 & 0.22 & -17.94 & -21.23 & -23.42 \\
\hline MACL & 100 & 41.66 & 0.199 & -17.91 & -20.91 & -22.91 \\
\hline DS & 100 & 48.11 & 0.214 & -15.75 & -18.97 & -21.11 \\
\hline DL & 100 & 54.47 & 0.239 & -16.75 & -20.34 & -22.73 \\
\hline
\end{tabular}

The values of $\Delta S^{\circ}, \Delta H^{\circ}$, and $\Delta \mathrm{G}^{\circ}$ were obtained from the slope and intercept, respectively, of the plot of lnKd versus $1 / \mathrm{T}$, as shown in fig. 16.The thermodynamic values of $\Delta \mathrm{S}^{\circ}, \Delta \mathrm{H}^{\circ}$, and $\Delta \mathrm{G}^{\circ}$ obtained for the adsorption of $\mathrm{Hg}$ (II) on DS, DL, MACS, and MACL are summarized in Table. 9. The enthalpy change is related to the chemical bonding; therefore, the positive value of the enthalpy of adsorption $\Delta \mathrm{H}^{\circ}$ obtained in this study confirms the endothermic nature of the adsorption process is likely due to chemisorption and strong interactions between the $\mathrm{Hg}$ (II) ions and the functional groups on the surface of the adsorbent. The value of $\Delta S^{\circ}$ is related to the ordering or geometry of the adsorbed ions. The positive value of $\Delta S^{\circ}$ suggests an increase in disorder and randomnessat the solid solution interface during the adsorption process. The standard Gibbs free energy change $\left(\Delta \mathrm{G}^{\circ}\right)$ is the fundamental criterion of spontaneity of an adsorption process. The negative values for $\Delta \mathrm{G}^{\circ}$ indicate that the adsorption process is spontaneous and thermodynamically favorable. The high negative values of $\Delta \mathrm{G}^{\circ}$ indicate a greater order of 
reaction and a stronger driving force the adsorption of $\mathrm{Hg}$ (II) on the surface of the modified water hyacinth activated carbon and dried water hyacinth.

\section{Desorption studies}

Recovery and regeneration study has become economically and environmentally attractive in recent years. The desorption study is not only helpful for providing scientific evidence of adsorption processes, but also for further application or disposal of the spent carbon. Desorption of adsorbed $\mathrm{Hg}$ (II) from spent adsorbent was carried out using different concentration of $\mathrm{HCl}(0.3-0.8 \mathrm{M})$ In order to investigate the desorption capacity of DS, DL, MACS and MACL, $0.025 \mathrm{~g}$ of different adsorbents were introduced to $25 \mathrm{ml}$ solution of 250 ppm of $\mathrm{Hg}(\mathrm{II})$ at $\mathrm{pH} 5$. As the adsorption reaches equilibrium, the metal ion concentration of the solution was measured, Then, the adsorbent loaded with $\mathrm{Hg}$ (II) was collected and treated with $25 \mathrm{ml} \times \mathrm{M} \mathrm{HCl}$ to remove the adsorbed $\mathrm{Hg}$ (II). Tables 10, 11, 12 revealed that the percent recovery of $\mathrm{Hg}(\mathrm{II})$ increased with increase of $\mathrm{HCl}$ from 0.3 to $0.8 \mathrm{M}$ and then remained constant. Desorption of $\mathrm{Hg}$ (II) by $\mathrm{HCl}$ can be attributed to the disruption of coordination with mercury ions. These results indicate that the removal of mercury from water by DS, DL, MACS, and MACL is mainly through affinity adsorption.

\begin{tabular}{|c|c|c|c|}
\hline \multicolumn{5}{|c|}{ Table1: Desorption of mercury using $\mathbf{0 . 3} \mathbf{M}$ HCl after adsorption of $250 \mathbf{p p m}$} \\
\hline Adsorbent code & qe adsorbed & qedesorped & \% desorption \\
\hline MACS & 80 & 43.105 & 53.9 \\
\hline MACL & 74 & 44.634 & 60.32 \\
\hline DL & 52 & 40.314 & 77.53 \\
\hline DS & 37 & 24.35 & 65.8 \\
\hline
\end{tabular}

\begin{tabular}{|c|c|c|c|}
\hline \multicolumn{5}{|c|}{ Table2: Desorption of mercury using $\mathbf{0 . 6} \mathbf{M} \mathbf{~ H C l}$ after adsorption of 250 $\mathbf{p p m}$} \\
\hline Adsorbent code & qe adsorbed & qedesorped & \% desorption \\
\hline MACS & 80 & 64.92 & 81.15 \\
\hline MACL & 74 & 53.4 & 72.2 \\
\hline$D L$ & 52 & 45.54 & 87.6 \\
\hline$D S$ & 37 & 30.1 & 81.4 \\
\hline
\end{tabular}

\begin{tabular}{|c|c|c|c|}
\hline \multicolumn{4}{|c|}{ Table3: Desorption of mercury using $\mathbf{0 . 8} \mathbf{M} \mathbf{~ H C l}$ after adsorption of 250 $\mathbf{p p m}$} \\
\hline Adsorbent code & qe adsorbed & qedesorped & \% desorption \\
\hline MACS & 80 & 64.92 & 81.15 \\
\hline MACL & 74 & 54.32 & 73.4 \\
\hline$D L$ & 52 & 45.94 & 88.351 \\
\hline$D S$ & 37 & 31.54 & 85.26 \\
\hline
\end{tabular}

\section{Mechanism of adsorption}

Finally, it would be of interest to present the mechanisms involved in the mercury removal process by dried water hyacinth and modified water hyacinth activated. In the previous section, it was observed that with progress of mercury adsorption, $\mathrm{pH}$ of solution continuously decreases. The increase in $\mathrm{H}^{+}$concentration in the adsorption medium can be related to the contribution of oxygen-containing functional groups on the dried water hyacinth and modified water hyacinth activated carbon in metal adsorption. FTIR spectrum also confirmed that $\mathrm{COOH}, \mathrm{OH}$ and $\mathrm{C}=\mathrm{O}$ are the main active groups present in activated carbon and water hyacinth. The following reactions between these groups and 
mercury ions during the mercury adsorption may be the reason of increasing the concentration of $\mathrm{H}^{+}$in the solution:

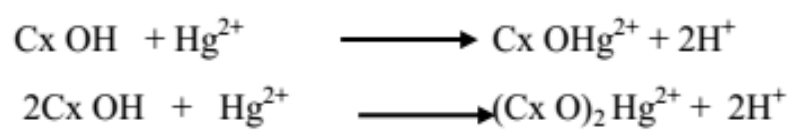

It is necessary to note that besides ion exchange, physical adsorption in the micro pores of activated carbon has an important part in the adsorption of mercury.

\section{Comparison of the adsorption capacities of sorbents toward $\mathrm{Hg}$ (II)}

Table 13 lists the comparisons of maximum adsorption capacities of DS, DL, MACS and MACL obtained in this study with various adsorbents previously used for the adsorption of $\mathrm{Hg}$ (II). These adsorbents have a higher adsorption capacity than that of the most other adsorbents reported in the literature, suggesting that it may be effective for $\mathrm{Hg}$ (II) removal from aqueous solution.

Table4: Comparison of the adsorption capacities of $\mathrm{Hg}$ (II) onto various adsorbents

\begin{tabular}{|c|c|c|}
\hline Adsorbents & $\begin{array}{l}\text { Adsorption } \\
\text { capacities } \\
(\mathrm{mg} / \mathrm{g})\end{array}$ & Ref. \\
\hline MACS & 102.6 & This \\
\hline MACL & 81.9 & work \\
\hline DS & 41.7 & \\
\hline DL & 57.59 & \\
\hline Granular activated carbon & 0.8 & \multirow{9}{*}[5,30,31]{} \\
\hline Dates nut carbon & 1.16 & \\
\hline Waste rubber & 4.0 & \\
\hline Commercial activated carbon & 12.38 & \\
\hline Eucalyptus camaldulensis bark & 33.1 & \\
\hline Carbon aerogel & 34.9 & \\
\hline Activated carbon prepared from sugercan bagasse & 35.71 & \\
\hline Sago waste carbon & 55.60 & \\
\hline Modified palm shell activated carbon & 83.33 & \\
\hline
\end{tabular}

\section{CONCLUSION}

Based on the results, it is clear that the mercury-removal values achieved with Nitric acid modified water hyacinth activated carbon were higher than those of dried water hyacinth due to the increase in the number of carboxylic groups on the surface of the modified activated carbon. The main advantages of this removal procedure include (i) simplicity,(ii) cost effectiveness,(iii) rapidity, and (iv) a higher removal efficiency of toxic mercury ions. Based upon the experimental results of this study, the following conclusions can be drawn:

-The maximum removal efficiency occurred at $\mathrm{pH}$ 5.0.

- The efficiency of mercury removal increased both with increased contact time and initial mercury concentration.

-The results showed that the adsorption increased rapidly till reach to the equilibrium time (60 $\mathrm{min})$.

- The experimental data were fitted well with the linear form of Langmuir model.

- Adsorption kinetics followed a pseudo-second-order model.

-Thermodynamic parameters, including $\Delta \mathrm{H}, \Delta \mathrm{G}$, and $\Delta \mathrm{S}$ for the adsorption process of mercury from aqueous solution onto dried water hyacinth and modified water hyacinth activated carbon indicated that adsorption was endothermic and spontaneous process. 


\section{REFERENCES}

A.A. Attia, B.S. Girgis, N.A. Fathy, Removal of methylene blue by carbons derived from peach stones by H 3 PO 4 activation: Batch and column studies, Dyes and Pigments, 76 (2008) 282-289.

A.A. Ismaiel, M.K. Aroua, R. Yusoff, Palm shell activated carbon impregnated with task-specific ionic-liquids as a novel adsorbent for the removal of mercury from contaminated water, Chemical Engineering Journal, (2013).

C.-H. Shin, J.-S. Bae, Performance of an activated carbon adsorber in a water reclamation system with an electrolysis reactor, Journal of Industrial and Engineering Chemistry, 15 (2009) 179-184.

C.P. Dwivedi, J. Sahu, C. Mohanty, B.R. Mohan, B. Meikap, Column performance of granular activated carbon packed bed for $\mathrm{Pb}$ (II) removal, Journal of hazardous materials, 156 (2008) 596-603.

D. Reichenberg, Properties of ion-exchange resins in relation to their structure. III. Kinetics of exchange, Journal of the American Chemical Society, 75 (1953) 589-597.

D. Sahoo, R. Kar, R. Das, Bioaccumulation of heavy metal ions by Bacillus circulans, Bioresource technology, 41 (1992) 177-179.

E. Demirbas, M. Kobya, M. Sulak, Adsorption kinetics of a basic dye from aqueous solutions onto apricot stone activated carbon, Bioresource technology, 99 (2008) 5368-5373.

F. Boudrahem, F. Aissani-Benissad, H. Ait-Amar, Batch sorption dynamics and equilibrium for the removal of lead ions from aqueous phase using activated carbon developed from coffee residue activated with zinc chloride, Journal of environmental management, 90 (2009) 3031-3039.

F.A. Pavan, A.C. Mazzocato, Y. Gushikem, Removal of methylene blue dye from aqueous solutions by adsorption using yellow passion fruit peel as adsorbent, Bioresource Technology, 99 (2008) 3162-3165.

G. Annadurai, D. Lee, R. Juang, Adsorption of heavy metals from water using banana and orange peels, (2003).

G. Boyd, A. AW, LS, Myers Exchange adsorption of ions by organic zeolites II: Kinetics J, Am. Chem. Soc, 69 (1947) 2836-2848.

J. Minczewski, J. Chwastowska, M.R. Masson, Separation and preconcentration methods in inorganic trace analysis, E. Horwood. Halsted Press, 1982.

J.-Y. Lee, T.-S. Kwon, K. Baek, J.-W. Yang, Adsorption characteristics of metal ions by CO2-fixing Chlorellasp. HA-1, Journal of Industrial and Engineering Chemistry, 15 (2009) 354-358.

M. Horvat, W. Baeyens, R. Ebinghaus, O. Vasiliev, Global and regional mercury cycles: sources, fluxes and mass balances, Kluwer Academic Publishers, Dordrecht. The Netherlands, (1996) P1.

M. Horvat, W. Baeyens, R. Ebinghaus, O. Vasiliev, Global and regional mercury cycles: sources, fluxes and mass balances, Kluwer Academic Publishers, Dordrecht. The Netherlands, (1996) P1.

M. Kobya, E. Demirbas, E. Senturk, M. Ince, Adsorption of heavy metal ions from aqueous solutions by activated carbon prepared from apricot stone, Bioresource Technology, 96 (2005) 1518-1521.

M.A. Zahran, The water hyacinth problem in Egypt, Proc.Symp. on Nile Water and Lake Dam projects, Nat. Res. Centre, Cairo ( 1976) 188-198.

M.M. Rao, D.H.K. Reddy, P. Venkateswarlu, K. Seshaiah, Removal of mercury from aqueous solutions using activated carbon prepared from agricultural by-product/waste, Journal of environmental management, 90 (2009) 634-643.

M.M. Rao, D.H.K. Reddy, P. Venkateswarlu, K. Seshaiah, Removal of mercury from aqueous solutions using activated carbon prepared from agricultural by-product/waste, Journal of environmental management, 90 (2009) 634-643.

M.U. Dural, L. Cavas, S.K. Papageorgiou, F.K. Katsaros, Methylene blue adsorption on activated carbon prepared from Posidonia oceanica(L.) dead leaves: Kinetics and equilibrium studies, Chemical Engineering Journal, 168 (2011) 77-85. 
Macías-García, A., et al. "Study of the pore size distribution and fractal dimension of $\mathrm{HNO}_{3}$-treated activated carbons." Applied surface science 252.17 (2006): 5972-5975.

N. Asasian, T. Kaghazchi, M. Soleimani, Elimination of mercury by adsorption onto activated carbon prepared from the biomass material, Journal of Industrial and Engineering Chemistry, 18 (2012) 283-289.

N. Feng, X. Guo, S. Liang, Adsorption study of copper (II) by chemically modified orange peel, Journal of Hazardous Materials, 164 (2009) 1286-1292.

N.K. Amin, Removal of reactive dye from aqueous solutions by adsorption onto activated carbons prepared from sugarcane bagasse pith, Desalination, 223 (2008) 152-161.

P. Bose, The problem of water hyacinth in Bengal, Sci. Cult, 11 (1945) 167-171.

P. Carrott, M. Carrott, J. Nabais, Influence of surface ionization on the adsorption of aqueous mercury chlorocomplexes by activated carbons, Carbon, 36 (1998) 11-17.

P.L. Bidstrup, Toxicity of Mercury and its Compounds, Toxicity of Mercury and its Compounds., (1964).

R. Gong, Y. Ding, H. Liu, Q. Chen, Z. Liu, Lead biosorption and desorption by intact and pretreated spirulina maxima biomass, Chemosphere, 58 (2005) 125-130.

T.W. Webi, R.K. Chakravort, Pore and solid diffusion models for fixed-bed adsorbers, AIChE Journal, 20 (1974) 228-238.

W. Weber, J. Morris, Kinetics of adsorption on carbon from solution, J. Sanit. Eng. Div. Am. Soc. Civ. Eng, 89 (1963) 31-60.

Y. Nuhoglu, E. Malkoc, Thermodynamic and kinetic studies for environmentaly friendly Ni (II) biosorption using waste pomace of olive oil factory, Bioresource Technology, 100 (2009) 2375-2380. 